\title{
ANALYSIS CRITERIA FOR REGIONAL RESILIENCE IN AREAS AFFECTED BY DISASTERS
}

\author{
CRITERIOS DE ANÁLISIS PARA LA RESILIENCIA REGIONAL EN ÁREAS \\ AFECTADAS POR DESASTRES
}

\author{
Giovanni Herrera Enríquez \\ Universidad de las Fuerzas Armadas-ESPE \\ gpherrera@espe.edu.ec \\ José Albuja Salazar \\ Universidad de las Fuerzas Armadas-ESPE \\ jnalbuja@espe.edu.ec \\ Eddy Castillo Montesdeoca \\ Universidad de las Fuerzas Armadas-ESPE \\ eacastillo@espe.edu.ec
}

\begin{abstract}
Resumen - El objetivo principal de esta investigación es definir la resiliencia dentro de los parámetros de los Sistemas Adaptativos Complejos y comprender su dinámica dentro del modelo heurístico de panarquía para evaluar las características de los sistemas regionales que podrían verse afectados por los desastres naturales. Los métodos analíticos y las variables identificadas son sistematizados y evaluados considerando la realidad de los territorios ubicados en países en desarrollo donde la información es deficiente o inexistente. La resiliencia es considerada multidimensional, de manera que se pueden identificar ocho dimensiones de análisis. Se propone 56 criterios de estudio que fueron obtenidos de diversos casos y opiniones de expertos de Ecuador y Chile.
\end{abstract}

Palabras Claves-Complejidad económica; Sistemas Adaptativos Complejos, desastres naturales, resiliencia regional.

Abstract - The main objective of this research is to define resilience within the parameters of Complex Adaptive Systems and to understand its dynamics within heuristic model of panarchy to evaluate the characteristics of the regional systems that could be affected by natural disasters. The analytical methods and variables identified are systemized and evaluated considering the reality of the territories located in developing countries where information is deficient or non-existent. Resilience is considered multidimensional, so that eight dimensions of analysis can be identified. We propose 56 study criteria that were obtained from various cases and opinions of experts from Ecuador and Chile.

Keywords - Economic complexity; complex adaptive systems, natural disasters, regional resilience

\section{INTRODUCCIÓN}

Many researcher [1]; [2]; [3] argue that the study of resilience has incorporated an important element for the decision-making process in the management of natural disasters. The physics is considered the basis of the concept; however, the main focus is humanity, from the point of view of psychology. [4] defines resilience as "a reduction of vulnerability of environmental risk experiences, stress and adversity overcome".

An important element is the recognition of inevitability predictability of "surprises" in the system with various unpredictable results such as the ecosystems capacity of self-organization within the unstable environment strengthening its structure and therefore its adaptability [5]; [6] always as long as provided that the magnitude of the disturbance is within the limits of the resilience in the system [7].

Within this context, the natural disasters are considered to have artificiality affectedness, in the majority of cases, randomly on social, ecological and economic systems. Moreover, the disturbance could result in three possible outcomes [8]: i) resilient reintegration, ii) homeostatic reintegration, iii) dysfunctional change and reintegration. In the first case adaptative change is produced which leads to the positive evolution of the affected region. In the second case, in turn, the adaptative change is present, but it is not always positive for the region, while in the third given situation, the adaptative change is not produced and the negative consequences of the event of adverse phenomenon continue or get worse.

\section{PANARCHY AND SOCIAL, ECONOMIC AND ECOLOGICAL SYSTEMS}

Before of the necessity to understand the adaptative change and the complexity of the relations between ecological, economic and organizational systems, the term of Panarchy should be considered. The main objective of Panarchy is 
to rationalize the interaction between the change and persistency between the predictable and unpredictable [9], is a heuristic model [10] which is able to adjust to the ideas of hierarchies and scales [11], to the order and disorder [12].

According to dynamics of complex adaptative systems (CAS) the special emphasis is into the emergency [9]; [13] and diversity [14], the interaction of which creates opportunities in the socio-ecological systems which permit the sustainable development. The framework of resilient, covers its evolutionary and adaptative nature. The answer to the question was found [15] "Why the world did not collapse despite the suffering natural disasters and social extremes?" First, because the ecological natural systems have the capacity of the recuperation after big catastrophes, maintaining the integrity of its functions and, second, because of human behavior and the creativity which leads people to adapt to the changes, not only through of the persistency in the passive form, but also through. The classical theories to approach the instability of the social and ecological systems do not have the answer to the question raised before, because they were designed for the equilibrium - the less probable scenario.

The adaptative cycle it is considered as a heuristic model (Figura I) which condenses CAS in four fundamental processes: exploitation, conservation, destruction and reorganization [15].

Figure I. Panarchy model and resilience

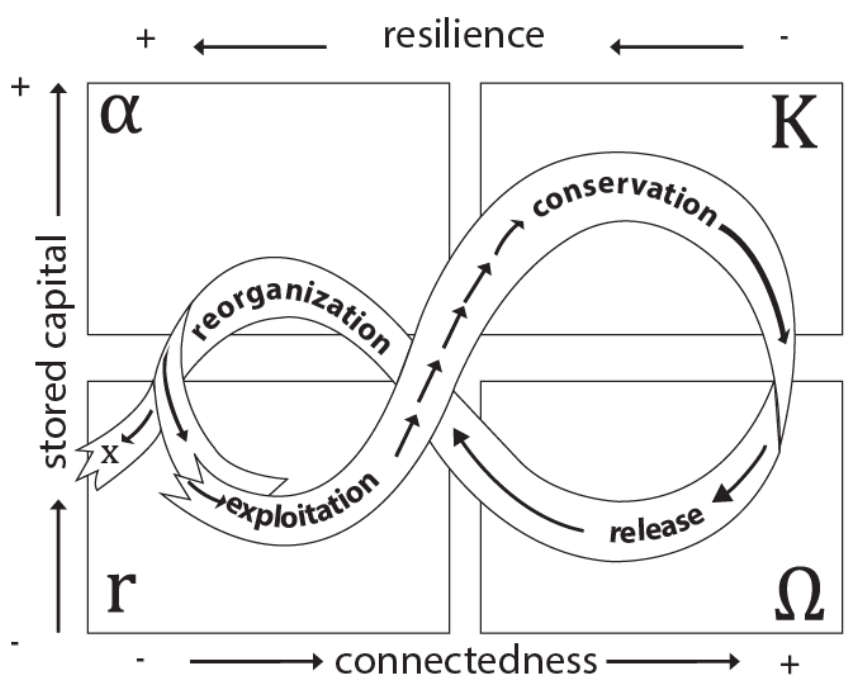

Source: Gunderson \& Holling, (2002)

In the dynamics of adaptative cycles there are four fundamental concepts: the stored capital (potential), the grade of internal control on variability (connectivity), vulnerability and resilience.

The heuristic model of panarchy permits to identify thresholds of opportunities and transformations [16]; [17]. The model also permits to approach two important phenomena: the change of regime and the novelty [10].

It is very complicated to determine the exact points where the regime changes occur, so there were proposed some tricks in order to be able to identify early signs that CAS is changing. For instance, [18] concluded that the increase of variability in CAS is the indicator that the system is entering to the transition phase (change of regime). On the other hand, [19] identify the previous state of flickering before any change take place in the system. Other important phenomena is the novelty, understood as a creation of new things or new combinations in the system through the natural and human generated process, the change of $\Omega$ to $\alpha$ in the panarchy model, the innovation viewed from this perspective is considered as a process where human beings are developing the novelty [10].

In economic and social terms the increase of population (phase from $r$ to $\mathrm{K}$ in the panarchy model) and the disproportionate use of resources and therefore the change of anthropogenic cover have left the humanity more vulnerable in front of the natural disasters [15] with its immediate consequences on human beings. The humans are trying to face the catastrophes and protect themselves against them, however, the uncertainty levels are increasing each time, when the consumerism is increasing (in the panarchy model is the phase $\mathrm{K}$ ) [20].

From the point of view of theoretical conception of resilience with the economic focus, it is evident that not many things are developed - the researches are centered on the regional economy and its relationship with environment. [21] presents the study that analyzes the complex interactions between economics, ecology and social systems based on hierarchy adaptation cycles of panarchy model. The use concept of resilience as a new emphasis for the studies of spatial economic systems in the light of diffusion dynamics of the innovation technology and adaptive behavior of the companies [22].

Through the case study, [23] review four properties of the resilience to evaluate the regional capacity: sturdiness, redundancy, ingenuity and rapidity. Via empirical application, [24] evaluates the usage of the regional resilience concept, which leads to the conclusion that the regional resilient management is not process or holistic system as it claims the ecological theory, but it is a process that requires the maintaining borders between spheres of resilience in the public, private levels and civic networks

By 2012, the application of the regional resilience concept is enlarged through the idea of "emergency" as a base of appearance of evolutionary process. [25] Could be underlined within recent publications because of the usage of the resilience concept in order to explain the capacity of the regions to reconfigure their socio-economic and institutional structures and to develop new growth paths taking into account its industrial composition, diversification and specialization levels under the evolutionary logic. 


\section{SOCIO - ECONOMIC RESILIENCE IN NATURAL DISASTERS}

There is series of elements that form a part of resilience concept in the environment of theoretical and empirical development. Those elements permit to distinguish the resilient systems from ones that are not resilient. Without establishing hierarchy, relative weight or its relationship dependency in the manner of first approximation, those elements are understood as "determinant factors". The work of [26] on resilience in the planning of territorial space makes an important abstraction of the related characteristics of those elements. However, they are not systematized and the definitions are dispersed in various research works, for instance, Holling in 1973 considering the case described above - researchers issued the importance from the theoretical framework - identified four fundamental capacities, which present complex adaptative systems and are inherent. Those four capacities are the capacity of learning, the selforganizational capacity, the adaptability and the capacity of transformation.

Despite the fact that there is no tool to evaluate resilience that analyzes all inherent complexity of socioecological systems [27], one proposal of identification of CAS capacities that promote resilience as la identification and systematization of critical factors is searching for support of investigation, which is developing nowadays in the special way of management of natural disasters.

\section{A. Dimensions of Resilience Analysis in Cases of Natural Disasters}

The definition of variables involved in the study is wide and requires a process of systematization. Probably, the proposal of [28] where it is grouped in six dimensions, is the most used in the study of resilience of communities affected by disasters. However, the last year events experience added new elements of analysis, especially in developing countries that have suffered the impact of major disasters [29]; [30]; [31], questioning the variables identified in studies as indicated. One of the main limitations of measuring resilience is on the quality of information. The vast majority of existing methodologies require data of longitudinal cohort studies in order to explain the phenomenon, in "developing economies", is difficult and often impossible task to obtain historical data. Although some macro indicators defined by international organizations such as ECLAC, IMF, WB, OAS, UN, etc. could be taken into account, on the micro level the information is deficient, which hinders any type of study.

The economic approach proposes 16 criteria that are addressed at two levels, firstly, at regional level (see Table 1) and, secondly, at an individual business level (see Table 2) [32].

TABLE 1.

Criteria of economic-regional dimension

\begin{tabular}{|c|c|c|}
\hline No. & Basic variable & Criterion \\
\hline 1 & Economic structure & $\begin{array}{l}\text { Poverty. Poverty index for } \\
\text { developing countries. }\end{array}$ \\
\hline 2 & Economic structure & $\begin{array}{l}\text { Income equity. } \\
\text { GINI index }\end{array}$ \\
\hline 3 & Economic structure & $\begin{array}{l}\text { Sectorial employment. Population } \\
\text { working in the primary sector. }\end{array}$ \\
\hline 4 & Economic structure & Employment. Working population. \\
\hline 6 & Economic structure & $\begin{array}{l}\text { Economic diversity. Herfindahl - } \\
\text { Hirschman HHI index }\end{array}$ \\
\hline 7 & Economic structure & $\begin{array}{l}\text { Female employment. Female } \\
\text { population working with } \\
\text { remuneration. }\end{array}$ \\
\hline 8 & Economic structure & $\begin{array}{l}\text { Economic dependency. Economic } \\
\text { dependency ratio. }\end{array}$ \\
\hline 9 & $\begin{array}{l}\text { Income and } \\
\text { consumption }\end{array}$ & $\begin{array}{l}\text { Regional affordability. Average } \\
\text { percentage of income spent on } \\
\text { housing. }\end{array}$ \\
\hline 10 & Housing & Population with homeownership. \\
\hline 11 & Logistics & $\begin{array}{l}\text { Catering. Commercial attraction } \\
\text { influence. }\end{array}$ \\
\hline 12 & $\begin{array}{l}\text { Economic } \\
\text { vulnerability }\end{array}$ & $\begin{array}{l}\text { Economic vulnerability. GDP per } \\
\text { capita in purchasing power parity. }\end{array}$ \\
\hline
\end{tabular}

Sources: Developed from documentary and field research.

The selection of 56 criteria considers investigations focused on resilience in response to catastrophic events in different geographic areas, emphasizing those related to communities and groups of people who have been affected primarily by natural disasters. The study considers each dimension within a particular scale analysis, each of which 
refers to heuristic model of panarchy, as could be seen in Fig. II. The panarchy cycles that represent each dimension are interrelated and feed the upper cycle (region) with actions that facilitate the processes of creative destruction and the reorganization of local/regional system after it has been affected by a disruptive event. In this situation the resilience is at minimal.

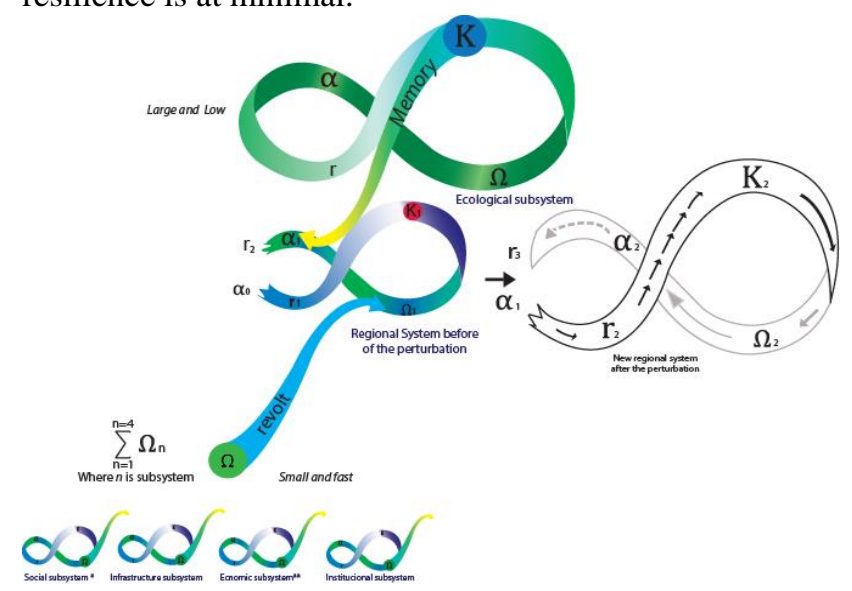

Figure II.- Multilevel interaction of the panarchy model in socio-ecological systems Source: [15]. [33]

The ecological dimension in those cases provides memory elements that allow adaptation of human systems to their natural environment whether they are altered or not (e.g. an alteration due to natural disaster), while other cycles, related to the human systems generate adaptive change triggers due to three essential characteristics: forecasting, communication and technology [15]. Thus, panarchy retains the ability to create, test and maintain resilience.

\section{B. Criteria for the evaluation of regional resilience}

The variables selected for the analysis of resilience were considered on the basis of diverse studies formed on CAS and panarchy heuristic model, as well as on the experience of 26 experts of Ecuador and Chile who participated in prevention, rescue and reconstruction processes of the disasters in central region of Chile with the earthquake and tsunami occurred on February 27, 2010, the earthquake of Coquimbo (Chile) occurred on September 16, 2015, the fire of Valparaiso (Chile) occurred on April 12, 2014, the eruption of Tungurahua volcano (from 1999 until these days - Ecuador) and the earthquake of the coast of Manabi and Esmeraldas in Ecuador occurred on April 16, 2016. The criteria for variable selection consider their relevance, functionality, availability, reliability and utility [34]; [35]; [36] for analysis of resilience in areas affected by natural disasters.

On the other hand, in the context of social approach there are 20 criteria identified that are addressed in three levels: first two - socio-regional (see Table 3) and socio-communal (see Table 4) refer to the research of [3], the third one, which is experiential dimension (see Table 5), analyses the conduct against catastrophic events adopted by the individual, community and institutions, as it is showed in the studies of [37]; [38], and [39]. The ecological dimension presents 2 criteria (see Table 6), infrastructural dimension presents 6 criteria (see Table 7), and the institutional one -8 criteria (see Table 8 ).

TABLE 2.

Criteria of business economy dimension

\begin{tabular}{rll}
\hline No & Basic variable & Criteria \\
\hline 1 & Entrepreneurship & $\begin{array}{l}\text { Opportunity. Entrepreneurial vision in } \\
\text { the disaster. }\end{array}$ \\
2 & Entrepreneurship & $\begin{array}{l}\text { Entrepreneurship levels per an } \\
\text { opportunity. }\end{array}$ \\
3 & $\begin{array}{l}\text { Business } \\
\text { environment }\end{array}$ & $\begin{array}{l}\text { Business environment. Acceptance of } \\
\text { entrepreneurs in the region. }\end{array}$ \\
4 & Entrepreneurship & $\begin{array}{l}\text { Company response to the effects of } \\
\text { the disaster. }\end{array}$ \\
5 & $\begin{array}{l}\text { Economic } \\
\text { structure }\end{array}$ & $\begin{array}{l}\text { Companies with female owners. } \\
\text { Sources: Developed from documentary and field research. }\end{array}$
\end{tabular}

Sources: Developed from documentary and field research.

TABLE 3.

Criteria of socio-regional dimension

\begin{tabular}{cll}
\hline No. & Basic variable & Criteria \\
\hline 1 & Education & $\begin{array}{l}\text { Education level. Average of } \\
\text { population schooling years. }\end{array}$ \\
& &
\end{tabular}




\begin{tabular}{|c|c|c|}
\hline 2 & Demographics & $\begin{array}{l}\text { Age of the population. Burgdofer } \\
\text { index. }\end{array}$ \\
\hline 3 & $\begin{array}{l}\text { Special } \\
\text { necessities }\end{array}$ & Population with disabilities. \\
\hline 4 & Demographics & $\begin{array}{l}\text { Gender. Households with women as } \\
\text { heads and their level of preparation } \\
\text { to a disaster. }\end{array}$ \\
\hline 5 & Education & Basic education. Illiteracy rate \\
\hline 6 & Demographics & $\begin{array}{l}\text { Population by occupation groups in } \\
\text { technical and professional levels. }\end{array}$ \\
\hline 7 & $\begin{array}{l}\text { Territorial } \\
\text { identity }\end{array}$ & Territorial identity of population. \\
\hline 8 & Healthcare & Health insurance coverage. \\
\hline 9 & Healthcare & $\begin{array}{l}\text { Medical coverage. Doctors per } 10,000 \\
\text { inhabitants. }\end{array}$ \\
\hline 10 & Religion & $\begin{array}{l}\text { Religious influence. Influence of } \\
\text { religious faith in resilient behaviors. }\end{array}$ \\
\hline 11 & $\begin{array}{l}\text { Territorial } \\
\text { identity }\end{array}$ & $\begin{array}{l}\text { Identity of the entrepreneur with the } \\
\text { territory. }\end{array}$ \\
\hline 12 & $\begin{array}{l}\text { Social } \\
\text { vulnerability }\end{array}$ & $\begin{array}{l}\text { Social vulnerability. Regional poverty } \\
\text { indicator per unsatisfied needs. }\end{array}$ \\
\hline
\end{tabular}

Sources: Developed from documentary and field research

TABLE 3

Criteria of socio-regional dimension

\begin{tabular}{|c|c|c|}
\hline No. & Basic variable & Criteria \\
\hline 1 & Education & $\begin{array}{l}\text { Education level. Average of population schooling } \\
\text { years. }\end{array}$ \\
\hline 2 & Demographics & Age of the population. Burgdofer index. \\
\hline 3 & $\begin{array}{l}\text { Special } \\
\text { necessities }\end{array}$ & Population with disabilities. \\
\hline 4 & Demographics & $\begin{array}{l}\text { Gender. Households with women as heads and their } \\
\text { level of preparation to a disaster. }\end{array}$ \\
\hline 5 & Education & Basic education. Illiteracy rate \\
\hline 6 & Demographics & $\begin{array}{l}\text { Occupation. Population by occupation groups in } \\
\text { technical and professional levels. }\end{array}$ \\
\hline 7 & $\begin{array}{l}\text { Territorial } \\
\text { identity }\end{array}$ & Identity. Territorial identity of population. \\
\hline 8 & Healthcare & Health insurance coverage. \\
\hline 9 & Healthcare & Medical coverage. Doctors per 10,000 inhabitants. \\
\hline 10 & Religion & Influence of religious faith in resilient behaviors. \\
\hline 11 & $\begin{array}{l}\text { Territorial } \\
\text { identity }\end{array}$ & Identity of the entrepreneur with the territory. \\
\hline 12 & $\begin{array}{l}\text { Social } \\
\text { vulnerability }\end{array}$ & $\begin{array}{l}\text { Social vulnerability. Regional poverty indicator per } \\
\text { unsatisfied needs. }\end{array}$ \\
\hline
\end{tabular}

Sources: Developed from documentary and field research.

TABLE 4.

Criteria of socio-community dimension

\begin{tabular}{cll}
\hline No. & Basic variable & Criteria \\
\hline 1 & Psychographics & $\begin{array}{l}\text { Individual and community resilience. Results } \\
\text { of RSA (Resilience Scale for Adults). }\end{array}$ \\
\cline { 3 - 3 } 2 & Networks & $\begin{array}{l}\text { Family cohesion. Results of RSA (Resilience } \\
\text { Scale for Adults). }\end{array}$ \\
\hline 3 & Networks & $\begin{array}{l}\text { Community cohesion. Results of RSA } \\
\text { (Resilience Scale for Adults). }\end{array}$ \\
\cline { 3 - 3 } 4 & Networks & $\begin{array}{l}\text { Associativity. Public participation in social } \\
\text { groups. }\end{array}$ \\
\hline 5 & Networks & $\begin{array}{l}\text { Solidarity. Results of RSA (Resilience Scale } \\
\text { for Adults). }\end{array}$ \\
\hline
\end{tabular}




\begin{tabular}{cll}
6 & Networks & Leadership. Trust in community leaders. \\
\cline { 3 - 3 } 7 & Institutionalism & $\begin{array}{l}\text { Institutional trust. Trust in the institutions } \\
\text { responsible for disaster management. }\end{array}$ \\
\hline 8 & $\begin{array}{l}\text { Business } \\
\text { environment }\end{array}$ & $\begin{array}{l}\text { Perceived level of social responsibility of the } \\
\text { employer to the community. }\end{array}$ \\
\hline
\end{tabular}

Sources: Developed from documentary and field research.

\section{TABLE 5}

Criteria of experiential dimension

\begin{tabular}{cll}
\hline No. & Basic variable & Criteria \\
\hline 1 & Risk perception & Perception on disaster training. \\
\cline { 3 - 3 } 2 & Risk perception & Risk perception. \\
\cline { 3 - 3 } 3 & Risk perception & $\begin{array}{l}\text { Security in the face of disaster. } \\
\text { Perception of security. }\end{array}$ \\
\cline { 3 - 3 } 4 & Risk perception & $\begin{array}{l}\text { Perception of experience in } \\
\text { disasters. }\end{array}$ \\
\cline { 3 - 3 } 5 & Risk perception & $\begin{array}{l}\text { Identification with the risk } \\
\text { management systems. System } \\
\text { identification levels of population. }\end{array}$ \\
\cline { 3 - 3 } 6 & Psychographics & $\begin{array}{l}\text { Economic expectations. } \\
\text { Expectations of post-disaster } \\
\text { improvement. }\end{array}$ \\
\hline 7 & Risk Perception & $\begin{array}{l}\text { Effects on health. Perception of } \\
\text { health involvement by the disaster. }\end{array}$ \\
\hline
\end{tabular}

Sources: Developed from documentary and field research.

TABLE 6.

Criteria of ecological dimension

\begin{tabular}{cll}
\hline No. & Basic variable & \multicolumn{1}{c}{ Criteria } \\
\hline 1 & $\begin{array}{l}\text { Natural } \\
\text { vulnerability }\end{array}$ & $\begin{array}{l}\text { Natural hazard risk. Regional risk } \\
\text { levels of threats, vulnerabilities and } \\
\text { capacities. }\end{array}$ \\
\cline { 3 - 3 } 2 & Biodiversity & $\begin{array}{l}\text { Ecological biodiversity. Territory } \\
\text { under conservation or } \\
\text { environmental management. }\end{array}$ \\
\hline
\end{tabular}

Sources: Developed from documentary and field research.

TABLE 7

Criteria of infrastructural dimension

Table 7. Criteria of infrastructural dimension

\begin{tabular}{cll}
\hline No. & Basic variable & \multicolumn{1}{c}{ Criteria } \\
\hline 1 & Basic services & $\begin{array}{l}\text { Basic services. Basic service } \\
\text { coverage. }\end{array}$ \\
\cline { 3 - 3 } 2 & $\begin{array}{l}\text { Public } \\
\text { infrastructure }\end{array}$ & $\begin{array}{l}\text { Health system infrastructure. Hospital } \\
\text { beds per 1,000 inhabitants. }\end{array}$ \\
\cline { 3 - 3 } 3 & Risk management & $\begin{array}{l}\text { Disaster monitoring. Existence of } \\
\text { monitoring systems. }\end{array}$ \\
\cline { 3 - 3 } 4 & Communications & Mobile network coverage. \\
5 & Public & $\begin{array}{l}\text { Lifelines for evacuation and supply. } \\
\text { Adequacy of access roads to the } \\
\text { infrastructure }\end{array}$ \\
\cline { 3 - 3 } 6 & Housing & $\begin{array}{l}\text { Urban planification. Housing with } \\
\text { construction permissions. }\end{array}$ \\
\hline
\end{tabular}

\section{CONCLUSIONS}

Due to exposed here is suggested the definition of resilience as a phenomenon of dynamic adaptability and learning of the system's ability to self-organizes without changing its essential functions during response to the impact of domestic and external shocks, enabling development, innovation and evolution of the system in focus. 
The proposed definition is based on the paradigm of complex adaptive systems (CAS) and its dynamics is understood from the steps of the panarchy heuristic model or, specifically for the current study, from the disturbing events that unleash the creative destruction in systems. This reorganization constitute a natural phenomenon that directly affect regional systems. Furthermore, it can be concluded that the heuristic model identifies opportunity and transformation also founded in [16]; [17] but within resilience limits. It is identified that the accumulation of capital (social, economic, ecological, etc.) is associated with a condition of conservation where resilience decreases [15] and where the risk of the disaster is raising due to the impact of an unforeseen natural phenomenon.

The result of proper management of resilience, is its acting as the process of identifying opportunities for development that configuring a modular process that avoid the collapse of the socio-ecological system.

On the other hand, from the theoretical perspective it is shown that resilience is multidimensional, in other words, that being a part of a complex adaptive system, the effects of a disturbance generate impacts on different "subsystems" and chain reactions that provoke evolutionary changes, homeostasis or dysfunctional changes. [39]. In this research, the resilience "subsystems" are classified into following eight dimensions: economic-regional, business-economic, socio-regional, socio-communal, experiential, institutional and infrastructural, each of which has a set of criteria that define and characterizes them. The defined criteria have an effect on resilience, as could be evidenced from the different referenced empirical studies. Consequently, its use through multidimensional approach methodologies can produce results that facilitate comparison between regions.

\section{REFERENCES}

[1] Adger, N., Hughes, T., Folke, C., Carpenter, S., \& Rockström, J. (2005). Social-ecological resilience to coastal disasters. Science, 1036-1039.

[2] Chandra, A., Acosta, J., Stern, S., Uscher-Pines, L., Williams, M., Yeung, D., . . Meredith, L. (2011). Building Community Resilience to Disasters. Pittsburgh: U.S Departament of Health and Human Servies.

[3] Cutter, S. L., Barnes, L., Berry, M., Burton, C., Evans, E., Tate, E., \& Webb, J. (2008). A place-based model for understanding community resilience to natural disasters.

[4] Rutter, M. (2006). Implications of resilience concepts for scientific understanding. Annals of the New York Academy of Sciences, 1-12.

[5] Holling, C. S. (1986). The Resilience of Terrestrial Ecosystems: Local surprise and global change. En W. C. Clark, \& R. Munn, Sustainable development of the biosphere (págs. 292-317). Cambridge: Cambridge University Press.

[6] Peterson, G., Allen, C. R., \& Holling, C. S. (1998). Ecological Resilience, Biodiversity, and Scale Ecological Resilience, Biodiversity, and Scale. Ecosystems, 6-18.

[7] Allen, C. R., \& Holling, C. S. (2008). Discontinuities in Ecosystems and other Complex Systems. New York: Columbia University Press.

[8] Kumpfer, K. (1999). Factors and processes contributing to resilience: The resilience framework. En M. Glantz, \& J. J.L., Resilience and Development: Positive life adaptations longitudinal research in the social and behavioral sciences. Dordfecht: Kluwer.

[9] Holling, C. S., Gunderson, L. H., \& Ludwing, D. (2002). In Quest of a Theory of Adaptative Change. En L. H. It was Gunderson, \& C. S. Holling, Panarchy. Understanding Transformations in Human and Natural Systems. Washington: Island Press.

[10] Allen, C. R., Angeler, D. G., Garmestani, A. S., Gunderson, L. H., \& Holling, C. (2014). Panarchy: Theory and Application. Ecosystems, 578-589.

[11] García, R. (2006). Sistemas Complejos. Conceptos, método y fundamentación epistemológica de la investigación interdisciplinaria. Barcelona: Gedisa S.A.

[12] Morín, E. (1981). El Método: La Naturaleza de la Naturaleza. Madrid: Cátedra.

[13] Holland, J. H. (1998). Emergence: From Chaos to Order. New York: Perseus Books Groups.

[14] Holland, J. H. (1995). Hidden Order. Haw adaptation builds complexity. USA: Helix Books.

[15] Gunderson, L., \& Holling, C. S. (2002). Panarchy: Understanding Transformations in Human and Natural System. Washington DC: Island.

[16] Evans, G. (2008). Transformation from "Carbon Valley" to a "Post-Carbon Society" in a Climate Change Hot Spot : the Coalfields of the Hunter Valley, New South. Ecology and Society, http://www.ecologyandsociety.org/vol13/iss1/art39.

[17] Van Apeldoorn, D. F., Kok, K., Sonneveld, M. P., \& Veldkamp, T. (2011). Panarchy Rules : Rethinking Resilience of Agroecosystems, Evidence from Dutch Dairy-Farming . Ecology and Society , http://www.ecologyandsociety.org/vol16/iss1/art39/.

[18] Carpenter, S., \& Brock, W. (2006). Rising variance: a leading indicator of ecological transition. Ecology Letters, 311-318.

[19] Scheffer, M., Bascompte, J., Brock, W., Held, H., Van Nes, E. H., Rietkerk, M., \& Sugihara, G. (2009). Earlywarning signals for critical transitions. Nature, 53-59.

[20] Kasperson, R., Kasperson, J., \& Turner, B. (1995). Regions at Risk: Comparisons of Threatened Environments 
(UN Studies on Critical Environmental Regions). Tokyo: United Nations University Press.

[21] Holling, C. S. (2001). Understanding the Complexity of Economic, Ecological, and Social Systems. Ecosystems, 390-405.

[22] Reggiani, A., Graaff, T., \& Nijkamp, P. (2002). Resilience: An evolutionary approach to spatial economic systems. Networks and Spatial Economics, 211-229.

[23] Foster, K. A. (2007). A Case Study Approach to Understanding Regional Resilience. IURD Working Paper Series, http://escholarship.org/uc/item/8tt02163. Berkeley: Institute of Urban and Regional Development, University of California.

[24] Swanstrom, T. (2008). Regional Resilience: A Critical Examinations of the Ecological Framework. Institute of Urban and Regional UC Berkeley, 1-34.

[25] Boschma, R. (2014). Towards an evolutionary perspective on regional resilience. Papers in Evolutionary Economic Geography. Utrech, Holland: Utrecht University. Urban \& Regional research centre Utrecht.

[26] Lu, P., \& Stead, D. (2013). Understanding the notion of resilience in spatial planning: A case study of Rotterdam, The Netherlands. Cities, 200-2012.

[27] Gall, M. (2013). From social vulnerability to resilience: measuring progress toward disaster risk reduction. Bonn: United Nations University.

[28] Cutter, S., Burton, C., \& Emrich, C. (2010). Disater Resilience Indicators for Benchmarking Baseline Conditions. Journal of Homeland Security and Emergency, 1-22.

[29] Harrions, C., \& Williams, P. (2016). A systems approach to natural disaster resilience. Simulation Modelling Practice and Theory, 1-21

[30] León, J., \& March, A. (2014). Simulation Modelling Practice and Theory. Habitat International, 250-262.

[31] Marcucci, D. (2014). Simulation Modelling Practice and Theory. Procedia Economics and Finance, 39-46.

[32] Rose, A., \& Liao, S.-Y. (2005). Modeling Regional Economic Resilience to Disasters: A Computable General Equilibrium Analysis of Water Service Disruptions. Journal of Regional Science, 75-112.

[33] Walker, B., Salt, D. (2012) Resilience Practice:Building Capacity to Absorb Disturbance and Maintain Function. Island Press.

[34] CONEVAL. (2013). Manual para el diseño y contrucción de indicadores. México: CONEVAL.

[35] DANE. (15 de 02 de 2016). Guía para Diseño, Contrucción e Interpretación de Indicadores. Obtenido de Departamento Administrativo Nacional de Estadística, http://www.dane.gov.co/files/planificacion/fortalecimiento/cuadernillo/Guia_construccion_interpretacion_indicadore s.pdf

[36] Sarandón, S. (2002). El desarrollo y uso de indicadores para evaluar la sustentabilidad de los agroecosistemas. En S. Sarandón, Agroecología. El camino hacia una agricultura sustentable (págs. 393-414). La Plata: Ediciones Científicas Americanas.

[37] Orencio, P. M., \& Fujii, M. (2013). A localized disaster-resilience index to assess coastal communities based on an analytic hierarchy process (AHP). International Journal of Disaster Risk Reduction, 62-75.

[38] Shaw, D., Scully, J., \& Hart, T. (2014). The paradox of social resilience: How cognitive strategies and coping mechanisms attenuate and accentuate resilience. Global Environmental Change, 194-203.

[39] Tierney, K., \& Bruneau, M. (2007). Conceptualizing and Measuring Resilience. A key to disaster loss reduction. TR News, 14-18.

[40] Constantino T, R. M., \& Dávila, H. (2011). Una aproximación a la vulnerabilidad y la resiliencia ante eventos hidrometeorológicos extremos en México. Política y Cultura, 1-46. 